\title{
Microstructure of Holstein and Gir breed adult bovine hooves: histomorphometry, three-dimensional microtomography and microhardness test evaluation
}

\author{
[Microestrutura de cascos de bovinos adultos das raças Holandesa e Gir: avaliação por \\ histomorfometria, microtomografia tridimensional e teste de microdureza] \\ R.E. Rabelo ${ }^{1}$, V.A.S. Vulcani ${ }^{1}$, F.J.F. Sant'Ana ${ }^{2}$, L.A.F. Silva ${ }^{3}$, \\ B.M. Assis ${ }^{1}$, G.H.M. Araújo ${ }^{1}$ \\ ${ }^{1}$ Universidade Federal de Goiás - UFG - Jataí, Goiás \\ ${ }^{2}$ Universidade de Brasília - UnB - Brasília, DF \\ ${ }^{3}$ Universidade Federal de Goiás - UFG - Goiânia, Goiás
}

\begin{abstract}
This study aimed to characterize and compare the aspects involved in the microstructural formation of the Holstein and Gir breed hoof wall by histomorphometry, three-dimensional microtomography and microhardness test techniques. Seventy-two $(18 \mathrm{H} / 18 \mathrm{G}$ thoracic and $18 \mathrm{H} / 18 \mathrm{G}$ pelvic) Holstein $(\mathrm{H})$ and Gir (G) breed hooves were collected in slaughterhouses. The hooves were divided into six groups according to breed and age group: 24 to 36 months $(\mathrm{C} 1 \mathrm{H} / \mathrm{C} 1 \mathrm{G}), 36$ to 60 months $(\mathrm{C} 2 \mathrm{H} / \mathrm{C} 2 \mathrm{G})$ and over 60 months $(\mathrm{C} 3 \mathrm{H} / \mathrm{C} 3 \mathrm{G})$. The normality and homogeneity analysis of morphometric variables by the Kolmogrov-Sminov and Bartlett tests was conducted as a statistical model. Once the assumptions were met, the Sigmastat 3.5 software was used and the means were compared by $\mathrm{T}$ test. The $5 \%$ probability level is considered. When the assumptions were not met, the means were compared by the Mann-Whitney nonparametric test, considering the 5\% probability level. When comparing the Holstein and Gir breeds, no differences were noticed between them as to the length of the dermal papillae; young animals showed thicker papillae than adult animals; the Holstein breed hooves showed higher amount of 7pores on the wall and on the sole compared to the Gir breed; Holstein cattle hooves showed greater microhardness than Gir cattle; there was no microhardness difference between pigmented and non-pigmented hooves of Holstein and Gir cattle.
\end{abstract}

Keywords: diseases of cattle, digits, three-dimensional microtomography, dermal papillae, podiatry

\section{RESUMO}

O presente estudo objetivou caracterizar e comparar os aspectos envolvidos na formação microestrutural do estojo córneo de bovinos das raças Holandesa e Gir pelas técnicas de histomorfometria, microtomografia tridimensional e teste de microdureza. Foram coletados em frigoríficos, de forma igualitária entre as raças Holandesa (H) e Gir (G), 72 cascos (18H/18G torácicos e 18H/18G pélvicos). Os cascos foram divididos em seis grupos de acordo com a raça e a faixa etária: 24 a 36 meses, (C1H/C1G), 36 a 60 meses $(\mathrm{C} 2 \mathrm{H} / \mathrm{C} 2 \mathrm{G})$ e acima de 60 meses $(\mathrm{C} 3 \mathrm{H} / \mathrm{C} 3 \mathrm{G})$. Como modelo estatístico, realizou-se análise de normalidade e homogeneidade das variáveis morfométricas empregando testes Kolmogrov-Sminov e Bartlett. Atendidas as pressuposições, empregou-se o programa Sigmastat 3.5 e compararam-se as médias pelo teste T. Considerou-se o nível de 5\% de probabilidade. Ao comparar as raças Holandesa e Gir, observou-se que não houve diferença entre elas quanto ao comprimento das papilas dérmicas. Os animais jovens apresentaram papilas mais espessas que os adultos. Os cascos da raça Holandesa apresentaram maior quantidade de poros na muralha e na sola em relação à raça Gir. Os cascos de bovinos Holandeses possuem microdureza maior que os de bovinos Gir. No estudo não se evidenciou diferença de microdureza entre cascos pigmentados e despigmentados de bovinos Holandeses e Gir.

Palavras-chave: doenças de bovinos, dígitos, microtomografia tridimensional, papilas dérmicas, podologia

Recebido de 16 de março de 2015

Aceito de 19 de junho de 2015

E-mail: rabelovet@yahoo.com.br 


\section{INTRODUCTION}

Given the challenges posed to cattle in the current production systems, hoof diseases have great relevance and are related to multifactorial causes. Among those causes, genetic, morphofunctional, infectious, nutritional and environmental aspects should be highlighted. Their interference with cellular and biochemical events involved in the formation and maintenance of the hoof wall should be considered (Ferreira et al., 2005; Muelling, 2009, Mendes et al., 2013). Those factors are the main causes of low productive and reproductive indexes, therefore determining relevant losses to cattle farms.

Podal diseases should be highlighted among the illnesses that affect cattle, especially those with dairy ability. Those diseases cause intense discomfort, manifested by lameness and difficulty for the animal to walk or stay in a quadrupedal position. Many studies have elucidated numerous concerns about the classification of the diseases that affect the hoof wall, etiopathogenesis, epidemiological aspects, treatment, and preventive and biosafety measures (Nicoletti, 2005; Greenough, 2007; Belge et al., 2012). However, basic studies focusing primarily on morphofunctional and development aspects of the hoof in the adult animal are still scarce and controversial, although those aspects have been recently studied in Holstein breed bovine fetus hooves (Rabelo et al., 2015). Therefore, the understanding of micro-structural, biochemical and mechanical resistance or microhardness aspects of the hoof wall are required in the search for tools that could bring improvements to the control and prevention of diseases affecting the cattle hooves.

This study aimed to characterize and compare the aspects involved in the microstructural formation of Holstein and Gir breed bovine hoof by histomorphometry, three-dimensional microtomography and microhardness test techniques, evaluating the amount, thickness, length and the cells that make up the epidermal papillae, as well as the porosity of keratinized epidermis and its microhardness.

\section{MATERIAL AND METHODS}

The project was submitted and approved by the Comitê de Ética no Uso de Animais na Experimentação Animal (CEUA) of the Universidade Federal de Goiás (UFG), under protocol 093/11.

Seventy-two (36 thoracic and 36 pelvic) female adult bovine hooves from Holstein and Gir breeds of different ages were collected in slaughterhouses (Tab. 1). One of the requirements for the inclusion of anatomical parts in the study was the absence of any podal change or disease. For that, the animals were inspected ante mortem and evaluated regarding podal health (Greenough, 2007). When choosing the animals, it was also considered whether they were originated from the same production system or farmed similarly. The digits were divided into six groups according to breed and age group (Tab. 1).

Table 1. Distribution of female adult bovine hoof groups by age group and breed.

\begin{tabular}{cccccc}
\hline Group & Breed & Age & $\begin{array}{c}\text { Total of } \\
\text { Hooves }\end{array}$ & $\begin{array}{c}\text { Thoracic } \\
\text { Hooves }\end{array}$ & $\begin{array}{c}\text { Pelvic } \\
\text { Hooves }\end{array}$ \\
\hline $\mathrm{C} 1 \mathrm{H}$ & Holstein & 24 to 36 months & 12 & 6 & 6 \\
$\mathrm{C} 1 \mathrm{G}$ & Gir & 24 to 36 months & 12 & 6 & 6 \\
$\mathrm{C} 2 \mathrm{H}$ & Holstein & 36 to 60 months & 12 & 6 & 6 \\
$\mathrm{C} 2 \mathrm{G}$ & Gir & 36 to 60 months & 12 & 6 & 6 \\
$\mathrm{C} 3 \mathrm{H}$ & Holstein & $>60$ months & 12 & 6 & 6 \\
$\mathrm{C} 3 \mathrm{G}$ & Gir & $>60$ months & 12 & 6 & 6 \\
\hline
\end{tabular}

C1H: Category 1 - Holstein; C1G: Category 1 - Gir; C2H: Category 2 - Holstein; C2G: Category 2 - Gir; C3H: Category 3 - Holstein; C3G: Category 3 - Gir.

For the conduction of histomorphometry, three-dimensional microtomography and microhardness examinations, the members, with their respective digits, were separated systematically, as described in Fig. 1. For every examination, 24 digits from every group were used. 


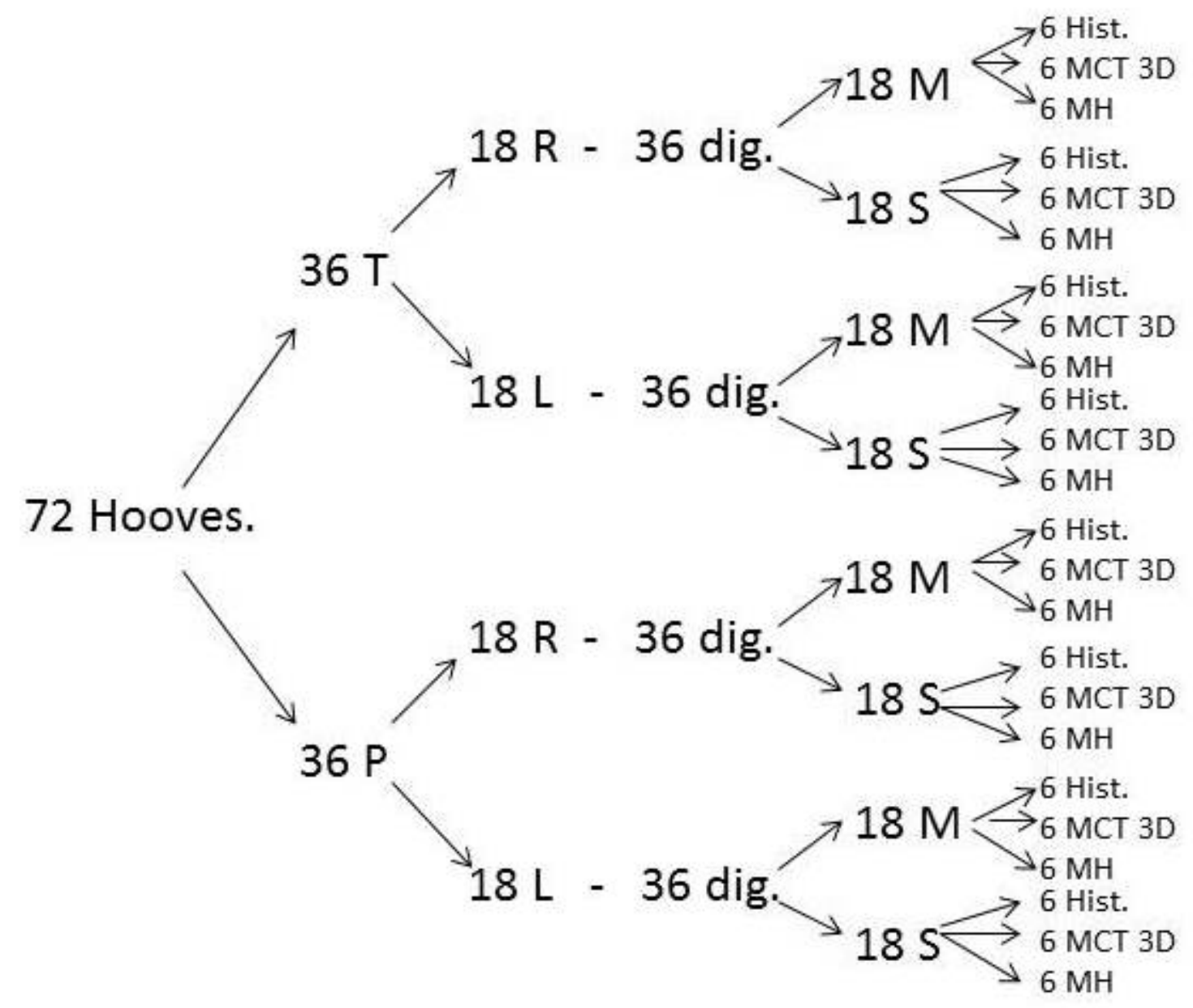

T: thoracic; P: pelvic; R: right; L: left; dig: digits; M: medial; S: side; Hist: histomorphometry; MCT 3D: three-dimensional microtomography; $\mathrm{MH}$ : microhardness.

Figure 1. Distribution of all samples collected for histomorphometry, three-dimensional microtomography and microhardness tests.

For the histomorphometric evaluation of the hoof wall, collections were conducted following methodology according to Mendonça et al. (2003). Clinical specimens of approximately 10 x $3 \mathrm{~mm}$ were collected in two points of the hoof, on the dorsal wall laminar corium and on the prebulbar sole. After the collections, the samples were immediately fixed in $10 \%$ neutral formaldehyde buffered solution, processed for inclusion in paraffin and stained with hematoxylin-eosin (HE). After the preparation of the slides, the microstructural development of epidermal papillae and the formation of the horn tubules were evaluated, by using a Zeiss-EM 10 optical microscope, with image capture device to record the various fields of every slide. Then, the length and thickness morphometry of the epidermal papillae was carried out as well as the morphometry of the spacing between those papillae, by using the Image ${ }^{\circledR}$ software. In the Holstein breed, the morphometric data of pigmented and non-pigmented hooves were also analyzed separately.

The cumulative mean test was conducted to estimate the minimum amount of epidermal papillae to be measured and evaluated, obtaining the total of 25 structures per sample. The normality and homogeneity analysis of morphometric variables by the KolmogrovSminov and Bartlett tests was conducted as statistical model. Once the assumptions were met, the Sigmastat 3.5 software was used and the means were compared by $\mathrm{T}$ test, considering the 
$5 \%$ probability level. When the assumptions were not met, the means were compared the by the Mann-Whitney non-parametric test, considering the $5 \%$ probability level (Sampaio, 2002).

Two samples of the hoof keratinized tissue (epidermis) of every region of the abaxial wall and three samples of the prebulbar sole, with approximately $10 \times 10 \mathrm{~mm}$, were taken from every digit to conduct three-dimensional microtomography and microhardness tests. Thereby, every sample was used for the conduction of the tests, corresponding to the respective groups. The samples collected were cleaned properly, ensuring the removal of soft tissue and dirtiness, placed in plastic containers and frozen at $-20^{\circ} \mathrm{C}$. The hoof three-dimensional microtomography evaluation was conducted in the Laboratório de Imagem e Modelamento of the Faculdade de Odontologia of the Universidade de São Paulo (USP), city of Ribeirão Preto, São Paulo state. This microstructural analysis was conducted in a $3 \mathrm{D}$ bench microscanner (model 1172, Sky Scan, Belgium) using the Data Viewer ${ }^{\circledR}$ and Ctan Ctvol ${ }^{\circledR}$ software, by following the procedure recommended by Silva (2009). The images obtained were correlated for the production of a three-dimensional model and compared as to the morphological differences according to every group studied. Similarly, the hoof wall microhardness evaluation was conducted with samples that were previously washed, dissected for the removal of soft tissues and fragmented in $10 \times 10 \mathrm{~mm}$ specimens. A polymer resin (T208 $\left[\right.$ Cristal $\left.{ }^{\circledR}\right]$ ) was prepared for insertion of the specimens in order to act as support and stabilize the samples. In addition, styrene monomer, MEK TGDM50 catalyst and dimethylamine were used in rates for hardening of approximately threeminutes. Then, fragments of the hoof samples were prepared for the microhardness test, according to the method used in the mechanical testing laboratory. For that, the fragments were inserted in five-centimeter aluminum cylinders and the resin was poured on the sample. After the resin drying, the aluminum cylinder was removed and the surface was worn, using wet and dry sanding paper with numbering ranging from 220 to 2,500 for the exhibition of the hoof fragments. Once prepared, the specimens were sent to the Laboratório de Transformação de Fases (Phase Transformation Laboratory) of the
Departamento de Engenharia de Materiais (Material Engineering Department) of the Escola de Engenharia (School of Engineering) of USP, city of São Carlos, São Paulo state, to be submitted to the Vickers microhardness tests in a Leica-branded microdurometer equipment, VMHT-MOT model, coupled to the light microscopy.

\section{RESULTS AND DISCUSSION}

The histomorphometric evaluation of the $\mathrm{C} 1 \mathrm{H}$ and $\mathrm{C} 1 \mathrm{G}$ group hooves revealed average length of epidermal papillae of 1,574.37 and 1,424.48 $\mu \mathrm{m}$, respectively (Tab. 2). In $\mathrm{C} 2 \mathrm{H}$, the length mean of these papillae was $1,315.57 \mu \mathrm{m}$ and, for the $\mathrm{C} 2 \mathrm{G}$ group it was $1,289.20 \mu \mathrm{m}$. For $\mathrm{C} 3 \mathrm{H}$ group hooves, the average value of the length of those structures was $1,252.05 \mu \mathrm{m}$, whereas in the $\mathrm{C} 3 \mathrm{G}$ it was $1,290.03 \mu \mathrm{m}$. No significant differences were observed $(\mathrm{P}>0.05)$ in comparisons among the breeds in their respective age groups. However, when comparing the average lengths of $\mathrm{C} 1 \mathrm{H}$ and $\mathrm{C} 1 \mathrm{G}$ groups with the other groups, a significant difference $(\mathrm{P}<0.05)$ was noted. Those data indicate that the epidermal papillae reduce their length as cattle become older, similarly to the findings by Mendonça (2003). Although support to assert this condition is not found in specialized literature, it is possible that older cattle hooves reduce the connection among the epidermal and dermal papillae, which could result in the weakening of the hoof structures and consequent greater vulnerability of the hoof to podal diseases.

Table 2. Mean $(\mu \mathrm{m})$ and standard deviation of the hoof epidermal papilla and length of Holstein and Gir breeds and age groups (C1 - 24/36 months; C2 - 36/60 months; C3 - >60 months)

\begin{tabular}{|c|c|c|}
\hline Age Group/Breed & Holstein & Gir \\
\hline $\mathrm{C} 1$ & $1,574.37 \pm 2.00 \mathrm{a}$ & $1,424.48 \pm 3.00 \mathrm{a}$ \\
\hline $\mathrm{C} 2$ & $1,315.57 \pm 1.5 b$ & $1,289.20 \pm 3.00 \mathrm{~b}$ \\
\hline $\mathrm{C} 3$ & $1,252.05 \pm 3.5 b$ & $1,290.03 \pm 2.00 b$ \\
\hline
\end{tabular}

Means followed by the same letter, in the same column, do not differ among themselves $(\mathrm{P}>0.05)$.

As for the thickness of the epidermal papillae, the means $113.88,77.21$ and $55.14 \mu \mathrm{m}$, were found in the Holstein breed respectively, in the $\mathrm{C} 1 \mathrm{H}, \mathrm{C} 2 \mathrm{H}$ and $\mathrm{C} 3 \mathrm{H}$ groups (Tab. 3). In Gir cattle, the average values of the same structures 
were $180.64,89.04$ and $63.27 \mu \mathrm{m}$ for $\mathrm{C} 1 \mathrm{G}, \mathrm{C} 2 \mathrm{G}$ and $\mathrm{C} 3 \mathrm{G}$, respectively. There were significant differences between the breeds within every age category and among the age categories for the same breed $(\mathrm{P}<0.05)$. Thus, it was noted that the average thickness values of the epidermal papillae were higher for the Gir breed, compared to the Holstein breed. Similar data were also found by Mendonça et al. (2003).

Table 3. Mean $(\mu \mathrm{m})$ and standard deviation of the epidermal papillae thickness in the Holstein and Gir breeds and age groups (C1 - 24/36 months; C2 - 36/60 months; C3 - >60 months)

\begin{tabular}{ccc}
\hline Age Group/Breed & Holstein & Gir \\
\hline C1 & $113.88 \pm 1.00 \mathrm{a}$ & $180.64 \pm 0.90 \mathrm{~b}$ \\
C2 & $77.21 \pm 1.00 \mathrm{c}$ & $89.04 \pm 0.80 \mathrm{~d}$ \\
C3 & $55.14 \pm 0.90 \mathrm{e}$ & $63.27 \pm 1.00 \mathrm{f}$
\end{tabular}

Means followed by different letters, in the same column or line, differ among themselves $(\mathrm{P}<0.05)$.

When comparing the spacing among the epidermal papillae, it was found that in $\mathrm{C} 1 \mathrm{H}$ and $\mathrm{C} 1 \mathrm{G}$ groups, the means were 5.89 and $3.21 \mu \mathrm{m}$, respectively. In $\mathrm{C} 2 \mathrm{H}$, the mean was $6.23 \mu \mathrm{m}$ and in $\mathrm{C} 2 \mathrm{G}$ it was $5.40 \mu \mathrm{m}$. In the last age group the average values consisted of $10.76 \mu \mathrm{m}$ for $\mathrm{C} 3 \mathrm{H}$ and $8.74 \mu \mathrm{m}$ for $\mathrm{C} 3 \mathrm{G}$. There was significant difference in the comparison between breeds and among age groups of the same breed $(\mathrm{P}>0.05)$ (Tab. 4). The larger spacing among the epidermal papillae of the Holstein breed hooves compared to the Gir cattle has also been proven previously (Mendonça et al., 2003). In addition, those authors found that the diameter of the papillae diminishes with age, which, in theory, would also decrease the production of keratin and could undermine the hooves and predispose them to podal diseases, corroborating the data of this work.

In Holstein breed pigmented and non-pigmented hooves, the thickness means of epidermal papillae were 73.77 and $36.46 \mu \mathrm{m}$, respectively, showing that there was significant difference $(\mathrm{P}<0.05)$. The results found in this study show that the epidermal papillae of pigmented hooves of Holstein breed cattle are thicker, suggesting that those anatomical structures would have greater ability to produce keratin, when compared to non-pigmented hooves (Fig. 2). This fact, in theory, could also justify the higher incidence of podal diseases in cattle presenting non-pigmented hooves, even when farmed similarly to animals with pigmented hoof, possibly due to the greater fragility of the hoof (Silva, 1999).

Table 4. Mean $(\mu \mathrm{m})$ and standard deviation of the spacing among the epidermal papillae in the Holstein and Gir breeds and age groups (C1 - 24/36 months; C2 - 36/60 months; C3 - >60 months)

\begin{tabular}{ccc} 
Age Group/Breed & Holstein & Gir \\
\hline C1 & $5.89 \pm 0.90 \mathrm{a}$ & $3.21 \pm 1.00 \mathrm{~b}$ \\
C2 & $6.23 \pm 0.80 \mathrm{c}$ & $5.40 \pm 0.90 \mathrm{~d}$ \\
C3 & $10.76 \pm 1.00 \mathrm{e}$ & $8.74 \pm 0.80 \mathrm{f}$
\end{tabular}

Means followed by different letters, in the same column or line, differ among themselves $(\mathrm{P}<0.05)$.

The analysis of the images obtained in the microscanner (Figs. 3 and 4) allowed the observation of the horn tubules percentage on the hoof of the cattle from different groups.

The average percentages of horn tubules in the keratin of the $\mathrm{C} 1 \mathrm{H}$ and $\mathrm{C} 1 \mathrm{G}$ hoof wall were $5.43 \%$ and $3.47 \%$, while in the $\mathrm{C} 2 \mathrm{H}$ and $\mathrm{C} 2 \mathrm{G}$ groups they corresponded to $5.68 \%$ and $4.10 \%$, respectively (Tab. 5). In the last groups, the values were $6.03 \%$ for $\mathrm{C} 3 \mathrm{H}$ and $5.09 \%$ for $\mathrm{C} 3 \mathrm{G}$. There was significant difference in the comparison between $\mathrm{C} 1 \mathrm{H}$ and $\mathrm{C} 1 \mathrm{G}, \mathrm{C} 2 \mathrm{H}$ and $\mathrm{C} 2 \mathrm{G}$ and $\mathrm{C} 3 \mathrm{H}$ and $\mathrm{C} 3 \mathrm{G}(\mathrm{P}<0.05)$. However, when the average values of every breed in different age groups were compared, no significant difference was noted. 


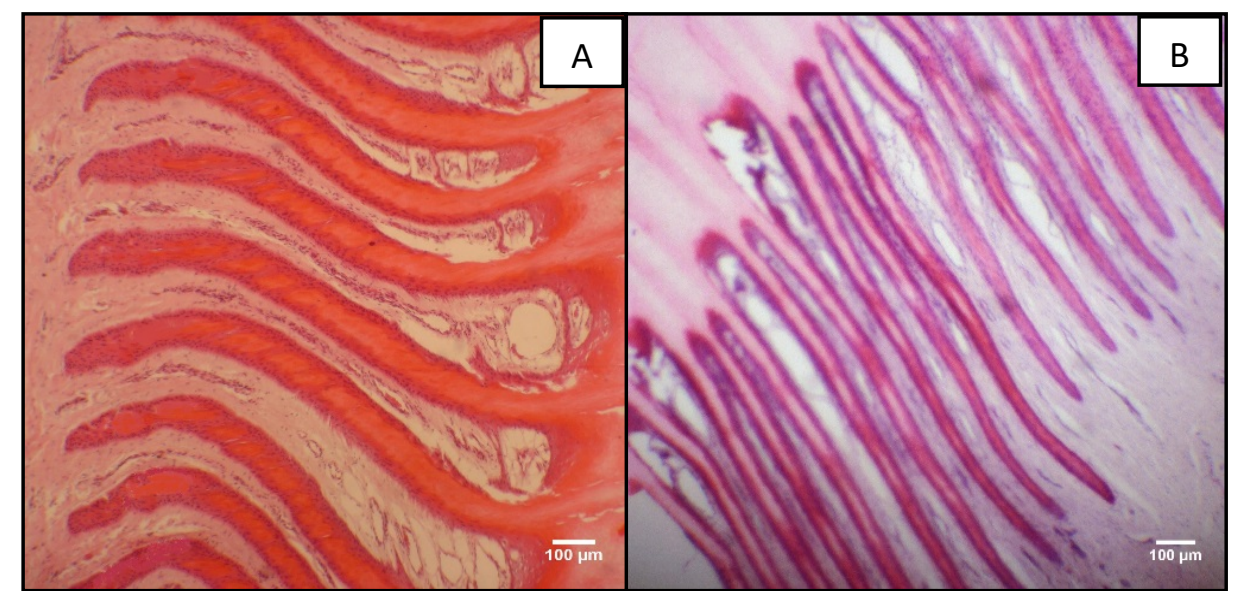

Figure 2. Epidermal papillae of the Holstein breed cattle hoof. In A, thick epidermal papillae of pigmented hoof and, in B, thin epidermal papillae of non-pigmented hooves. HE, 10X obj.

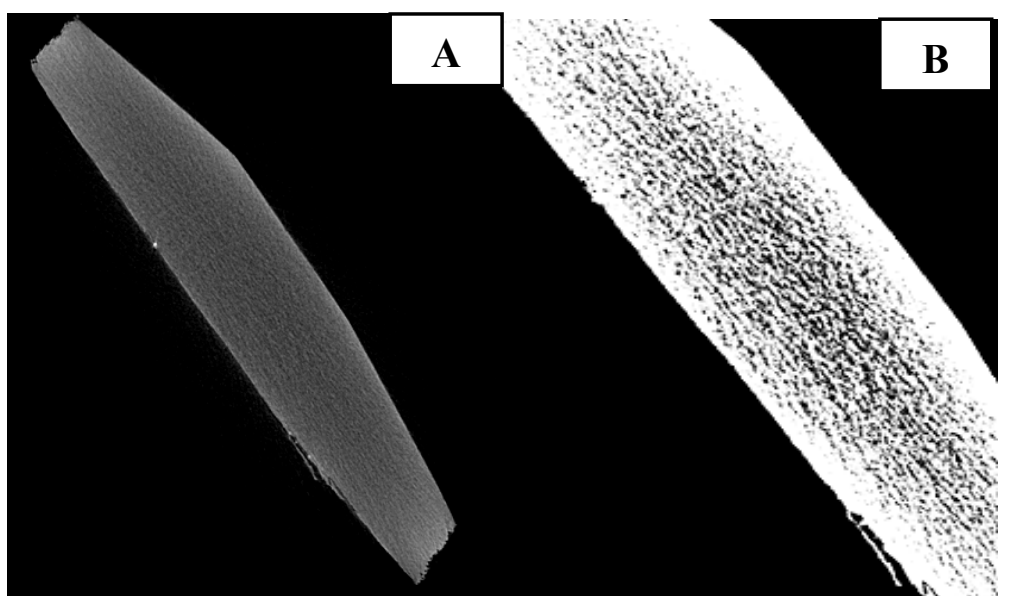

Figure 3. In A, illustrative representation of the image obtained by microtomography of the sole of Holstein breed adult bovine hooves. In B, color and contrast change of the image for analysis of horn tubules percentage.

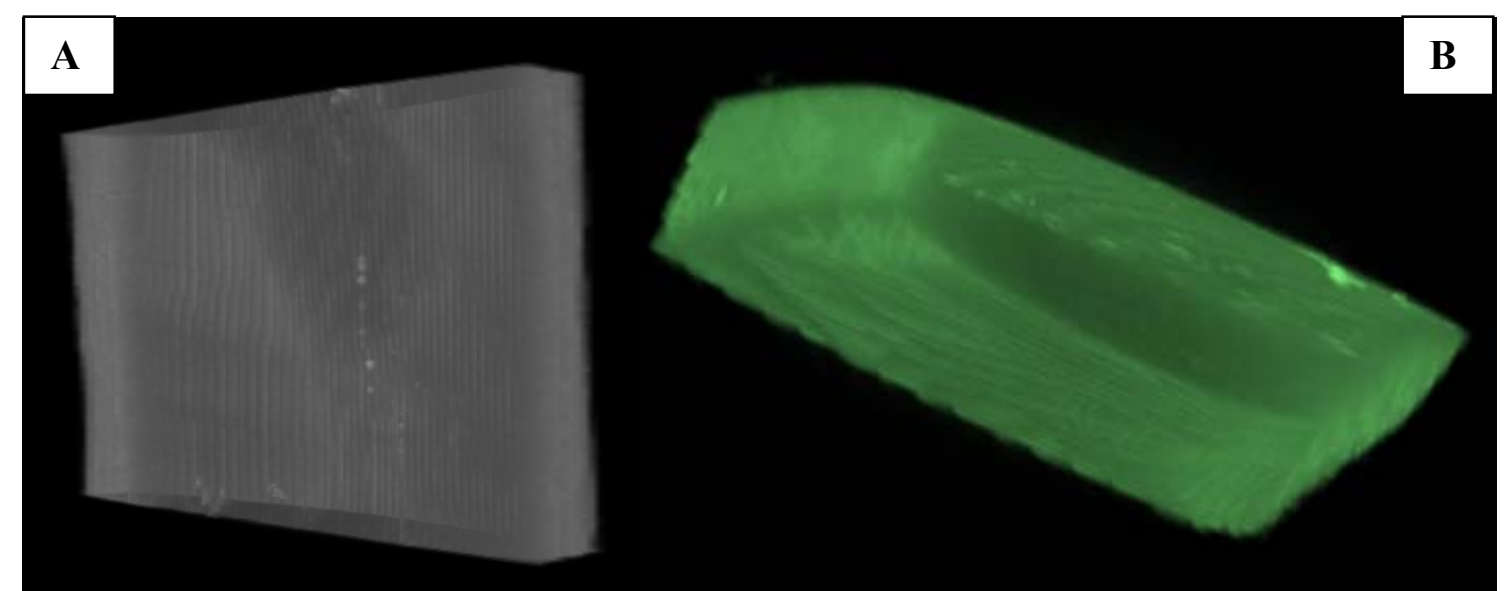

Figure 4. In A and B, representation of three-dimensional reconstruction of the images obtained from the keratin sample of the sole of the Gir breed adult bovine hooves. The image in B had the coloring, contrast and rotation changed. 
Table 5. Average percentage (\%) and standard deviation of the horn tubules in the keratinized epidermis of the hoof wall in the Holstein and Gir breeds and age groups (C1 - 24/36 months; C2 - 36/60 months; C3 - > 60 months)

\begin{tabular}{ccc}
\hline Age Group/Breed & Holstein & Gir \\
\hline C1 & $5.43 \pm 0.90 \mathrm{a}$ & $3.47 \pm 0.80 \mathrm{~b}$ \\
$\mathrm{C} 2$ & $5.68 \pm 1.00 \mathrm{a}$ & $4.10 \pm 0.90 \mathrm{~b}$ \\
$\mathrm{C} 3$ & $6.03 \pm 0.90 \mathrm{a}$ & $5.09 \pm 0.80 \mathrm{~b}$
\end{tabular}

Means followed by different letters, in the same line, differ among themselves $(\mathrm{P}<0.05)$.

The average values of horn tubules on the keratin of hoof soles were $6.50 \%$ for the $\mathrm{C} 1 \mathrm{H}$ group and $4.6 \%$ for the $\mathrm{C} 1 \mathrm{G}(\mathrm{P}<0.05)$, whereas the average percentages for $\mathrm{C} 2 \mathrm{H}$ and $\mathrm{C} 2 \mathrm{G}$ were $6.29 \%$ and $4.38 \%$, respectively $(\mathrm{P}<0.05)$ (Table 6$)$. In the $\mathrm{C} 3 \mathrm{H}(5.78 \%)$ and $\mathrm{C} 3 \mathrm{G}(4.33 \%)$ groups, a significant difference between those values $(\mathrm{P}<0.05)$ was also noted. However, similarly to what was noted with the mean of horn tubules in the keratin of the hoof wall, there was no difference among breeds when the $\mathrm{C} 1, \mathrm{C} 2$ and C3 groups were compared.

Table 6. Average percentage (\%) and standard deviation of the horn tubules in the keratinized epidermis of the hoof sole in the different breeds and age groups.

\begin{tabular}{ccc}
\hline Age Group/Breed & Holstein & Gir \\
\hline $\mathrm{C} 1$ & $6.50 \pm 1.00 \mathrm{a}$ & $4.6 \pm 0.90 \mathrm{~b}$ \\
$\mathrm{C} 2$ & $6.29 \pm 0.90 \mathrm{a}$ & $4.38 \pm 0.80 \mathrm{~b}$ \\
$\mathrm{C} 3$ & $5.78 \pm 1.00 \mathrm{a}$ & $4.33 \pm 0.90 \mathrm{~b}$
\end{tabular}

Means followed by different letters, in the same line, differ among themselves $(\mathrm{P}<0.05)$.

The comparison among the average values of horn tubules on the wall and hoof sole keratin showed significant difference in three age groups $(\mathrm{C} 1, \mathrm{C} 2$ and $\mathrm{C} 3)$, i.e., the wall shows a percentage of horn tubules lower than the percentage of the sole, which could be related to differences in mechanical strength. In theory, a large amount of horn tubules provides greater tissue fragility (Lima et al., 2009; Lopes et al., 2012).

Relevant data were noticed only in the Holstein breed when pigmented and non-pigmented hooves were compared and there was significant difference among the average percentages of horn tubules on the soles. The pigmented hooves showed a $2.35 \%$ mean of horn tubules in the keratin of the sole and the non-pigmented hooves a $4.29 \%$ mean $(\mathrm{P}<0.05)$. A similar result was noted on the mean of tubular keratin on the walls of the pigmented and non-pigmented hooves, which showed, respectively, $0.21 \%$ and $0.83 \%$ $(\mathrm{P}<0.05)$. The comparison of the tubular keratin means between the wall and the sole, for animals with pigmented and non-pigmented hooves, showed a significant difference $(\mathrm{P}<0.05)$.

Regarding microhardness tests, when the Holstein breed hooves were compared, it was noted that the microhardness mean of the wall was $7.7 \mathrm{~kg} / \mathrm{mm}^{2}$, while the microhardness mean of the sole was $5.3 \mathrm{~kg} / \mathrm{mm}^{2}(\mathrm{P}<0.05)$. Similarly, in the Gir breed hooves, there was significant difference between the wall and the sole (5.9 and $4.1 \mathrm{~kg} / \mathrm{mm}^{2}$, respectively) $(\mathrm{P}>0.05)$. Those results are corroborated by the findings of Rajkondawar et al. (2010), who also detected differences between the keratin microhardness of the hoof and sole wall. When the wall and sole microhardness between the breeds was compared, it was noted that there is a significant difference $(\mathrm{P}<0.05)$ among the means, demonstrating that the Holstein breed hooves show microhardness greater than the Gir breed hooves. Although there is no support in specific studies on microhardness of hooves, it could be inferred, based on what occurs in the structure of materials, that the microhardness may be a predisposing factor for the structural fragility of the Holstein breed hooves (Tombolato et al., 2010; McKittrick et al., 2010). The hoofs that have bigger microhardness can be the least flexible. The greater microhardness of hoof can mean it is the least flexible. This way, the greates hardness hoof can show predispositon to microfractures and crevices. Therefore a large microhardness is not sinonimous of resistence. This fact could be associated, in some ways, to the greater susceptibility of this breed to the emergence of podal diseases.

Regarding the Holstein breed hooves, it was noted that pigmented and non-pigmented hooves showed $6.7 \mathrm{~kg} / \mathrm{mm}^{2}$ wall microhardness mean and $4.3 \mathrm{~kg} / \mathrm{mm}^{2}$ sole microhardness mean $(\mathrm{P}<0.05)$. In Gir breed animals, there was significant difference between the wall and the sole $\left(5.9 \mathrm{~kg} / \mathrm{mm}^{2}\right.$ and $\left.4.1 \mathrm{~kg} / \mathrm{mm}^{2}\right)$. Those results are corroborated by other studies (Rajkondawaret 
al., 2010), which also used Vickers microhardness tests and stated that there is difference between the keratin microhardness of the hoof and sole wall. When the microhardness of the pigmented and non-pigmented hoof walls was compared, it was noted that there is no significant difference $(\mathrm{P}>0.05)$ among the means, which were $8.7 \mathrm{~kg} / \mathrm{mm}^{2}$ and $5.9 \mathrm{~kg} / \mathrm{mm}^{2}$, respectively. Similarly, the comparison among the sole microhardness means showed significant difference $\left(7.1 \mathrm{~kg} / \mathrm{mm}^{2}\right.$ and $\left.4.0 \mathrm{~kg} / \mathrm{mm} 2\right)$. It is considered that the pigmented hoof's microhardness when compared to the dispigmented is related to the higher capacity of keratin synthesis and other structural elements. Accordingly, the pigmented hooves can form more sulfate bonds and present higher number of horn tubules per area, conferring more resistance to the hooves.

\section{CONCLUSIONS}

Based on this study, it may be concluded that: 1there is no significant difference in the epidermal papillae length of the hoof between the Holstein and Gir breeds; 2-young Holstein and Gir breed animals have increased epidermal papillae length of the hoof when compared to adult animals; 3Gir animals have thicker epidermal papillae of the hoof than the Holstein breed animals; 4Holstein and Gir breed young animals show thicker epidermal papillae of the hoof when compared to adult animals; 5-Holstein breed animal hooves show a higher percentage of horn tubules on the wall and on the sole compared to the Gir breed; 6 - the hoof wall of Holstein and Gir breed animals has a lower amount of horn tubules when compared to the sole; 7 - the nonpigmented hooves of Holstein breed animals have a higher percentage of horn tubules than pigmented hooves; 8 - Holstein breed cattle hooves have larger microhardness than Gir animals; 9 - there is no microhardness difference between pigmented and non-pigmented hooves of Holstein and Gir breed animals.

\section{ACKNOWLEDGEMENTS}

The authors are grateful for the financial support of $\mathrm{CNPq}$ - Conselho Nacional de Desenvolvimento Científico e Tecnológico (Process 471820/2011-3) and FAPEG Fundação de Amparo à Pesquisa do Estado de Goiás (Process 201210267001041).

\section{REFERENCES}

BELGE, A.; AKIN, I.; TUNCA, R.; OZMEN, E. Histopathological changes in uncomplicated sole ulcers in dairy cattle. Turk J. Vet. Anim. Sci., v.36, p.642-645, 2012.

FERREIRA, P.M.; CARVALHO, A.U.; FILHO, E.J.F. et al.. Afecções do sistema locomotor dos bovinos. In: SIMPÓSIO MINEIRO DE BUIATRIA, 2., 2005, Belo Horizonte. Anais... Belo Horizonte: [Associação de Buiatria de Minas Gerais], 2005. p.24.

GREENOUGH, P.R. Bovine laminitis and lameness:a hands-on approach. Philadelphia: Saunders Elsevier, 2007. p.311.

LIMA, L.; LOPES, R.T.; OLIVEIRA, L.F.; ALVES, J.M. Análise de estrutura óssea através de microtomografia computadorizada. Rev. Bras. Fís. Méd., v.2, p.6-10, 2009.

LOPES, A.P.; FIORI, A.P.; REIS NETO, J.M. et al. Análise tridimensional de rochas por meio de microtomografia computadorizada de raios $\mathrm{x}$ integrada à petrografia. Geociências, v.31, p.129142, 2012.

MCKITTRICK, J.; CHEN, P.Y.; TOMBOLATO, L. et al. Energy absorbent materials and bio inspired design strategies: a review. Mater Sci. Eng., v.30, p.331-342, 2010.

MENDES, H.M.F.; CASAGRANDE, F.P.; LIMA, I.R. et al. Histopathology of dairy cows' hooves with signs of naturally acquired laminitis. Pesqui. Vet. Bras., v.33, p.613-619, 2013.

MENDONÇA, A.C.; SILVA, L.A.F.; FIORAVANTI, M.C.S. et al. Aspectos morfológicos dos dígitos de bovinos das raças Gir e Holandesa. Ciênc. Anim. Bras., v.4, p.53-60, 2003.

MUELLING, C.K.W. Nutritional influences on horn quality and hoof health. WCDS Adv. Dairy Tecnol., v.21, p.283-291, 2009.

NICOLETTI, J.L.M. Manual de podologia bovina. Barueri: Manole, p.125, 2004.

RABELO, R.E.; VULCANI, V.A.S.; SANT'ANA, F.J.F. et al. Histomorphological evaluation of digital coronary region at different fetal development stages of holstein cattle. Arq. Bras. Med. Vet. Zootec., v.67, p.1-6, 2015. 
RAJKONDAWAR, P.; ZHANG, D.; AROLA, D.; TASCH, U. Mechanical characterization of bovine hooves: comparing healthy and ailing hooves. In: ANNUAL CONFERENCE \& EXPOSITION ON EXPERIMENTAL AND APPLIED MECHANICS, 2010, Bethel, USA. Anais... Bethel: [s.n.] 2010. p.255-258.

SAMPAIO, I.B.M. Estatística aplicada à experimentação animal. Belo Horizonte: FEPMVZ, 2002. p.114.

SILVA, A.M.H. Análise morfométrica 2D e 3D de amostras de osso trabecular utilizando microtomografia tridimensional por raio-x. 2009. 78f. Dissertação (Mestrado em Bioengenharia) Escola de Engenharia de São Carlos, Universidade de São Paulo, São Carlos, SP.
SILVA, R.G. Estimativa do balanço térmico por radiação em vacas holandesas expostas ao sol e à sombra em ambiente tropical. Rev. Bras. Zootec., v.28, p.1403-11, 1999.

TOMBOLATO, L; NOVITSKA, E.; CHEN, P. et al. Microstructure, elastic properties and deformation mechanisms of horn keratin. Acta. Biomater., v.6, p.319-330, 2010. 